business activities continue to be carried out even in the context of the introduction of restrictive measures in Ukraine. It is stated that diagnostic equipment, vaccines, drugs and other medical devices and equipment designed to combat COVID-19 have become especially relevant during the coronavirus pandemic, but due to the growing demand for these products, the number of illegal acts has increased, even though at risk to public health. It is noted that recently, especially in the conditions of quarantine, illegal hacking activities are more and more often carried out, which requires careful monitoring and prevention of implementation by the state control bodies. It is concluded that it is necessary to strengthen the administrative and criminal liability of business entities for illegal activities, which was revealed as a result of unscheduled inspections. It was also concluded that it is necessary to introduce and use high technologies and attract intellectual capital by state control bodies as the main factors for effective detection of illegal activities in the modern world.

Keywords: state control, business entities, counteraction to the coronavirus pandemic, quarantine, illegal business activity, intellectual capital, responsibility of business entities.

\section{DOI: 10.33766/2524-0323.90.155-170 \\ УДК 342.951:614.46:351.77}

\author{
М. А. Самбор, \\ кандидат юридичних наук, \\ начальник сектора моніторингу \\ Прилуцького відділу поліції \\ Головного управління \\ Національної поліції в Чернігівській області \\ (м. Чернігів - м. Прилуки, Україна) \\ e-mail: NIKOLAS783@ukr.net \\ iD https:/ / orcid.org/ 0000-0002-0446-3892
}

\title{
СКЛАД АДМІНІСТРАТИВНОГО ПРАВОПОРУШЕННЯ ШОДО ПОРУШЕННЯ ПРАВИЛ КАРАНТИНУ ЛЮДЕЙ
}

У статті досліджується склад адміністративного правопорушення за ст. $44^{3}$ Кодексу України про адміністративні правопорушення, якою доповнено Кодекс законом України від 17 березня 2020 року. В умовах світової та всеукраїнської соціальних криз, зумовлених поширенням коронавірусної інфекції, що загрожує життю і здоров'ю людей, Верховною Радою України запроваджено адміністративну відповідальність за порушення правил щодо карантину людей. Нормі ст. $44^{3}$ КУпАП з часу розробки законопроекту не притаманні правова визначеність, зрозумілість. Аналіз складу цього адміністративного правопорушення дійти висновку про неоднозначність сприйняття законності ухвалення органами місцевого самоврядування відповідних обмежень, недотримання яких тягне адміністративну відповідальність за вказаною статтею. Крім того, з'ясовано, що запроваджені зміни до КУпАП створили конкуренщію норм Загальної та Особливої частин КУпАП. Невдало викладена норма створює непорозуміння й у з'ясуванні суб'єкта правопорушення. Доцільно було б розмежувати адміністративну відповідальність фізичних осіб та посадових осіб суб'єктів господарювання.

Ключові слова: адміністративне правопорушення, юридичний склад, правила карантину людей. 
Постановка проблеми. Ефективність реагування поліцейських на правопорушення, як адміністративні, так і кримінальні, у тому числі порушення правил карантину людей, не можливе без декількох основоположних елементів: знань, умінь та навичок реалізащії повноважень поліщії з надання поліцейських послуг щодо забезпечення публічної безпеки, виявлення та припинення адміністративних правопорушень, здійснення профілактичної та превентивної діяльності з виявлення та усунення причин й умов, що сприяють вчиненню порушень правил карантину людей, як адміністративного правопорушення.

Ефективність адміністративно-деліктного права - це здатність норм адміністративно-деліктного права врегульовувати суспільні відносини, що виникають унаслідок вчинення адміністративних правопорушень, у відповідності до інтересів суспільства, котрі виступають підгрунтям прийняття таких норм та визначають їх цілі й завдання, 3 дотриманням принципів верховенства права, дотримання прав і свобод людини, законності [1, с. 48]. Ефективність адміністративно-деліктного права досягається якісним застосуванням норм, законністю під час застосування адміністративної відповідальності. Зазначене досягається правильним розумінням та встановленням складу адміністративного правопорушення.

Аналіз останніх досліджень і публікацій. Дослідження складів адміністративних правопорушень у різних сферах здійснювали Р. А. Калюжний, С. В. Пєтков, О. Ю. Дрозд, М. В. Лошицький та інші автори. Вивченню надзвичайних правових режимів приділяли увагу О. М. Бандурка, Ю. П. Битяк, С. В. Ківалов тощо. Водночас життя само привносить нові актуальні питання, які потребують правового регулювання та формування науково-теоретичної основи їх аргументації. Одним із таких факторів став коронавірус і його поширення країнами світу та в Україні. У процесі протидії такої біологічної загрози важливою складовою захисту та протидії $є$ пошук форм, методів, які забезпечили б досягнення позитивних результатів - зниження рівня захворюваності та смертності, створення ефективного противірусного засобу, здатного знешкоджувати коронавірусну інфекцію, а також ефективні засоби правового впливу на суспільні відносини щодо унормування останніх. Особливості реагування спеціалізованих служб та проведення аварійно-рятувальних робіт стали предметом наукових досліджень В. І. Мазуренка, М. А. Самбора та О. Д. Гудовича, а саме правових основ тактики дій поліцейських в умовах надзвичайних ситуацій [2], А. В. Сергєєв досліджував правові основи діяльності органів внутрішніх справ в умовах надзвичайних ситуацій техногенного та природного характеру [3]. Однак питання реагування органів (підрозділів) Національної поліції на порушення карантину людей залишаються поза увагою дослідників, хоча ситуація, яка склалася у світі та Україні, потребує прискіпливої уваги до вирішення вказаного питання, науковотеоретичного їх обгрунтування для забезпечення єдності та однозначності правозастосування уповноваженими суб'єктами.

Формулювання цілей. Ураховуючи викладене, метою даної статті є з'ясування елементів складу адміністративного правопорушення за порушення карантину людей, визначення їх змістовного наповнення та особливостей формулювання, формулювання пропозищій щодо внесення змін до КУпАП, спрямованих на усунення наявної конкуренщії та колізії норм. 
Виклад основного матеріалу. Ефективність реагування поліцейських на порушення правил карантину людей, відповідальність за які передбачено ст. $44^{3}$ КУпАП, не можливе без з' ясування та розуміння наступних складових: 1) умов, у яких ухвалювалося рішення про встановлення адміністративної відповідальності за порушення правил щодо карантину людей; 2) мета, яка переслідується запровадженням адміністративної відповідальності за порушення правил щодо карантину людей; 3) розуміння складу адміністративного правопорушення за порушення правил щодо карантину людей; 4) аналіз практики застосування адміністративної відповідальності за порушення правил щодо карантину людей, що дозволяє сформувати правові уміння документування адміністративного правопорушення; 5) реагування на повідомлення про порушення правил щодо карантину людей; 6) узагальнення порядку реагування на повідомлення про порушення правил щодо карантину людей; 7) на підставі узагальнення практики реагування та протидії правопорушенням про порушення правил щодо карантину людей, ухвалення нормативно-правових актів, якими визначити порядок та правила реагування на повідомлення про порушення правил щодо карантину людей та їх документування, що створить умови для діяльності органів Національної поліції (виконавчої влади) у межах та спосіб, визначених Конституцією та законами України. Детальніше розглянемо перші три складові, які з точки зору теорії гарантують якість правозастосування.

Кодекс України про адміністративні правопорушення [4] (далі - КУпАП) Законом України «Про внесення змін до деяких законодавчих актів України, спрямованих на запобігання виникненню і поширенню коронавірусної хвороби (COVID19)» [5] (далі - Проект Закону), Верховною Радою України доповнено статтею $44^{3}$ «Порушення правил щодо карантину людей».

Об'єктивність, повноту та всебічність дослідження розуміння змісту норм позитивного права доречно розпочати із законодавчої інічіативи та законопроектних робіт.

У пояснювальній записці до Проекту Закону, реєстраційний номер № 3219 від 16.03.2020 [6], у якості обгрунтування необхідності ухвалення проекту даного закону зазначається, що наразі у світі склалася надзвичайна ситуація, пов' язана з можливим виникненням пандемії COVID-19 у світі та епідемії в Україні. Станом на 15 березня 2020 року в Україні зареєстровано 3 лабораторно підтверджених випадки COVID-19, один $з$ яких закінчився летально. 3 метою запобігання поширенню коронавірусу COVID-19 серед населення України підготовлено проекту закону України про внесення змін до деяких законодавчих актів України, спрямованих на запобігання, виникнення і поширення коронавірусної хвороби (COVID-19).

Вважаємо, що таке обгрунтування для норми адміністративно-деліктного законодавства України недоречне, оскільки власне адміністративна відповідальність, яку запропонували запровадити за певні діяння, навряд чи прямо стосується саме запобіганню коронавірусу COVID-19, як інфекційної хвороби, яка потребує медичного лікування. Хоча поряд із рядом інших негативних чинників, правова складова входить до цілісної низки тих елементів, запровадження яких забезпечує системність протидії коронавірусної інфекції.

Водночас у Висновку на Проекту Закону, реєстраційний номер № 3219 від 16.03.2020, підготовленому Головним науково-експертним управлінням (далі - ГНЕУ) стверджується, що запропонована редакція викликає низку зауважень, адже сама на- 
зва статті є вужчою за ї̈ зміст та не охоплює такі форми об'єктивної сторони правопорушення, як порушення санітарно-гігієнічних, санітарно-протиепідемічних правил і норм, передбачених Законом України «Про захист населення від інфекційних хвороб», іншими актами законодавства, а також рішень органів місцевого самоврядування з питань боротьби з інфекційними захворюваннями. Поняття «карантин людей», є юридично некоректним. ГНЕУ не погодилося з пропозищією проекту щодо встановлення адміністративної відповідальності за порушення правил щодо карантину людей, санітарно-гігієнічних, санітарно-протиепідемічних правил і норм, передбачених «іншими актами законодавства, а також рішень органів місцевого самоврядування з питань боротьби з інфекційними захворюваннями». Така позиція обумовлена тим, що об'єктивні ознаки того чи іншого адміністративного правопорушення мають бути чітко викладені в статті (частині статті) Особливої частини КУпАП та зрозумілими для суб'єктів правозастосування. Така невизначеність є неприпустимою для законодавства про адміністративні правопорушення [7].

Вказане дозволяє дійти висновку про те, що запровадження адміністративної відповідальності за перелічені діяння, у тій, первозданній формі, характеризується невизначеністю, незрозумілістю складу даного адміністративного правопорушення, про що наголошувалося під час проведення експертизи Проекту Закону. Недосконалість норми закону негативно позначатиметься й на регулюванні суспільних відносин, що призводитиме до невдоволення населення не лише засобами регулювання суспільних відносин - нормами закону, а й суб' єктами законотворення та правозастосування. Незважаючи на застереження ГНЕУ, рішення про доповнення КУпАП вказаною статтею відповідного змісту було ухвалено Верховною Радою України. Упевнені в тому, що така поспішність була викликана необхідністю вжиття активних заходів з боку інститутів держави, спрямованих на захист населення країни від надзвичайно небезпечної хвороби, викликаної вірусною інфекцією, необхідністю збереження життя і здоров'я людини, населення в цілому. Водночас вважаємо, що неприпустимо ставити під загрозу позбавлення чи обмеження прав і свобод людини та громадянина в угоду протидії хворобі. 3 іншого боку, запровадження заходів, які прямо призводять до обмеження прав і свобод людини та громадянина мають відповідати соціально значущій цілі та підтверджувати те, що людина, їі права і свободи є найвищою соціальною цінністю, повинні бути максимально досконалими, а не ухваленими в угоду політичній доцільності. Причому жодних переваг чи привілеїв не має бути залежно від статі, національності, місця проживання, соціального статусу чи матеріального забезпечення людини.

Однак органи Національної поліції України та їх посадові особи - поліцейські, які є посадовими особами органів виконавчої влади, зобов' язані виконувати закони, які ухвалені законодавчим органом влади - Верховною Радою України - і є обов' язковими для виконання всіма. Не є винятком з цього й необхідність здійснення контролю за дотриманням членами суспільства обмежень, за недотримання чи невиконання яких нормою ст. $44^{3}$ КУпАП встановлена адміністративна відповідальність.

Звертаючи увагу на адміністративно-процесуальну (адміністративно-процедурну) складову, зазначимо, що, відповідно до п. 1 ч. 1 ст. 255 КУпАП, протоколи про адміністративні правопорушення за ст. $44^{3}$ КУпАП мають право складати уповноважені посадові особи Національної поліції. 
Спираючись на норми ст. 8 Закону України «Про Національну поліцію», ч. 2 ст. 7 КУпАП, для здійснення своїх повноважень виключно на підставі, у межах повноважень та в спосіб, що визначені Конституцією та законами України, поліції необхідні знання про суть адміністративного правопорушення за ст. $44^{3}$ КУпАП, якого неможливо досягнути, не з'ясувавши складу цього правопорушення.

Склад - це опис діяння в законі. Опис ще не вчиненого, а тільки передбачуваного чи можливого діяння. Для такого опису використовуються лише юридично значущі ознаки, які характеризують діяння як правопорушення [8, с. 43]. Склад адміністративного правопорушення - це сукупність найбільш загальних, типових ознак окремих адміністративних правопорушень, необхідних та достатніх для притягнення правопорушника до адміністративної відповідальності. Склад адміністративного правопорушення складається з наступних елементів: 1) суб' єкт адміністративного правопорушення; 2) об'єкт адміністративного правопорушення; 3) об'єктивна сторона адміністративного правопорушення; 4) суб'єктивна сторона адміністративного правопорушення [9, с. 40].

Необхідність протидії коронавірусної інфекції змушує використовувати всі доступні засоби, у тому числі й заходи державного примусу, під час застосування яких важливим є правильно визначити об'єкт правопорушення, що стане запорукою законності під час провадження у справі про адміністративне правопорушення, а також підтримання верховенства права в суспільних відносинах, урегульованих позитивним правом.

За ступенем узагальнення об'єкт поділяється на загальний, родовий, безпосередній. Загальним об'єктом необхідно вважати всю сукупність значних суспільних відносин, які охороняються законодавством, зокрема й адміністративним. Суспільні відносини, які окреслюють зміст загального об'єкта, не можна охарактеризувати як постійні, а тому важливо враховувати, що загальному об'єктові властиві зміни, що обумовлюються розвитком суспільства, його прогресом. Так виникають принципово нові правовідносини, які, своєю чергою, можуть потребувати охорони з боку держави. Уся сукупність суспільних відносин, що складають загальний об'єкт адміністративного правопорушення, закріплена в ст. 9 КУпАП. До неї належать: громадський порядок, власність, права і свободи громадян, встановлений порядок управління. Для розуміння родового об' єкта значення відіграють групи правопорушень та ті критерії, за якими вони об'єднуються, ті громадські чи соціальні цінності, на які здійснюється посягання. Найчастіше групи родових об'єктів збігаються із розділами кодексів, що містяться в особливих частинах [10, с. 136]. Практична значущість загального об'єкта адміністративного проступку проявляється не лише в ході кваліфікації, але й при запровадженні нових адміністративно-деліктних норм. Встановлюючи юридичну відповідальність за певне діяння, законодавець має попередньо визначитись із тим, на яку сферу суспільних відносин воно посягає та, відповідно, який саме тип відповідальності (адміністративну, кримінальну, цивільну, дисциплінарну тощо) воно повинно за собою тягнути [11, с. 16]. Отже, загальним об'єктом адміністративного правопорушення, відповідальність за вчинення якого передбачена ст. $44^{3}$ КУпАП, є права і свободи громадян, власність, конституційний лад України, права і законні інтереси юридичних осіб, встановлений правопорядок, законність, запобігання правопорушенням, громадський порядок, встановлений порядок управління, що є результатом 
розуміння завдань адміністративно-деліктного законодавства в цілому, тих суспільних відносин, які перебувають під захистом заборонних норм КУпАП.

Очевидно, що родовим об'єктом адміністративного правопорушення, відповідальність за вчинення якого передбачена ст. $44^{3}$ КУпАП, є суспільні відносини у сфері охорони праці та здоров'я населення, адже саме в главі КУпАП з цією назвою законодавець умістив ст. $44^{3}$ КУпАП. Таким об'єктом адміністративного правопорушення, відповідальність за вчинення якого передбачена ст. $44^{3}$ КУпАП, є саме охорона здоров'я - система заходів, що здійснюються органами державної влади та органами місцевого самоврядування, їх посадовими особами, закладами охорони здоров'я, фізичними особами - підприємцями, які зареєстровані в установленому законом порядку та одержали ліщензію на право провадження господарської діяльності з медичної практики, медичними та фармацевтичними працівниками, громадськими об'єднаннями і громадянами з метою збереження та відновлення фізіологічних і психологічних функцій, оптимальної працездатності та соціальної активності людини при максимальній біологічно можливій індивідуальній тривалості ії життя (абзац 9 ч. 1 ст. 3 Закону України «Основи законодавства України про охорону здоров' я» [12]).

На думку вчених, виділення видового об'єкта є необхідністю, оскільки саме така система об' єктів детально розмежовує суспільні відносини між собою i, як наслідок, дозволяє правозастосовцю білы якісно здійснювати процес кваліфікації адміністративних правопорушень й ефективно призначати винним особам адміністративні покарання» [13, с. 82]. Розуміння того, що подія, про яку йдеться у зверненні до органів Національної поліції, пов' язана із забезпеченням збереження здоров'я населення, дозволяє правильно визначити комплекс адміністративних правопорушень, які можуть вчинятися в суспільних відносинах, поєднувана указаним об'єктом.

Переконані в тому безпосереднім об'єктом правопорушення за ст. $44^{3}$ КУпАП є саме суспільні відносини із захисту населення від інфекційних хвороб, із запобігання виникненню і поширенню таких інфекційних хвороб людини, локалізації та ліквідації їх спалахів та епідемій, пов'язані із порушеннями правил щодо карантину людей, санітарно-гігієнічних, санітарно-протиепідемічних правил і норм.

Об' єктивна сторона складу проступку - це зовнішній прояв суспільно-небезпечного посягання на об'єкт, що перебуває під охороною адміністративно-правових санкцій. Відповідно до цього, об'єктивну сторону складу адміністративного правопорушення утворюють ознаки, що характеризують зовнішні прояви проступку. Тобто, це система передбачених нормою адміністративного права ознак, які характеризують зовнішню сторону правопорушення. В об'єктивну сторону входили наступні ознаки: 1) протиправне діяння (чи дії бездіяльності) - розкрадання, пияцтво, торгівля, придбання, зберігання, використання, ухилення, управління, допуск тощо; 2) час і місце його здійснення; 3) спосіб здійснення правопорушення; 4) результат правопорушення; 5) причинний зв'язок між діянням і результатом; 6) суспільна небезпека (шкідливість), що визначається виходячи з усіх ознак об'єктивної сторони шляхом їхнього синтезу [14]. Саме об’ єктивна сторона відбивається в нормах статей Особливої частини КУпАП, зокрема в ст. $44^{3}$ КУпАП, і являє собою 1) порушення правил щодо карантину людей, 2) порушення санітарно-гігієнічних правил і норм, 3) порушення санітарно-протиепідемічних правил і норм. Указані діяння можуть 
бути вчинені у виді дії - активної поведінки, коли суб'єкт вчиняє дії, прямо заборонені законом, так і бездіяльності суб'єкта - пасивної поведінки, зумовленої невиконанням обов' язків суб'єктом, встановлених законом та визначених у рішеннях органів місцевого самоврядування.

Обов' язковим елементом об' єктивної сторони є посилання на те, що вказані норми іправила повинні міститися в нормах:1) Закону Украӥни «Про захист населення від інфекційних хвороб», 2) інших актах законодавства, 3) рішень органів місцевого самоврядування з питань боротьби з інфекційними хворобами. Отже, абсолютно визначеним нормативно-правовим актом, у якому мають бути визначені відповідні норми і правила, пов'язані із встановленням карантину, є Закон України «Про захист населення від інфекційних хвороб». До інших актів законодавства належать закони України, чинні міжнародні договори України, згода на обов'язковість яких надана Верховною Радою України, а також постанови Верховної Ради Украӥни, укази Президента України, декрети і постанови Кабінету Міністрів України, прийняті в межах їх повноважень та відповідно до Конституції України і законів України [15].

Окремо визначено рішення органів місцевого самоврядування з питань боротъби з інфекційними хворобами. Ухвалення таких рішень кореспондується із нормами, які передбачені п. 2 ч. 3 ст. 43 Закону Украӥни «Про місцеве самоврядування в Украӥні» [16], де зазначається, що виключно на пленарних засіданнях обласних рад вирішуються такі питання прийняття в межах, що визначаються законами, рішень із питань боротьби з епідеміями, які передбачають за їх порушення адміністративну відповідальність. Згідно з підпунктом 6 п. «б» ст. 33 Закону Украӥни «Про місцеве самоврядування в Україні», до відання виконавчих органів сільських, селищних, міських рад належать делеговані повноваження вжиття необхідних заходів щодо ліквідаціі наслідків надзвичайних ситуацій відповідно до закону, інформування про них населення, залучення в установленому закономпорядку до цих робітпіпприемств, установ та організацій, а також населення. Підпункт 2 п. «б» ч. 1 ст. 38 Закону України «Про місцеве самоврядування в Україні» відносить до відання виконавчих органів сільських, селищних, міських рад делеговані повноваження із вжиття в разі надзвичайних ситуацій необхідних заходів відповідно до закону щодо забезпечення державного і громадського порядку, життєдіяльності підпгриємств, установ та організацій, врятування життя людей, захисту їх здоров'я, збереження матеріальних цінностей.

Таким чином, пересвідчуємося, що органи місцевого самоврядування можуть ухвалювати відповідні рішення, пов'язані із встановленням карантинних, санітарногігієнічних та санітарно-протиепідемічних норм і правил. У відповідності до ст. 5 КУпАП, сільські, селищні, міські, обласні ради мають право приймати в межах, що визначаються законами, рішення з питань боротьби зі стихійним лихом й епідеміями, які передбачають за їх порушення адміністративну відповідальність, а також рішення з питань боротьби з епізоотіями, за порушення яких відповідальність встановлено статтею 107 КУпАП. Сільські, селищні, міські ради встановлюють відповідно до законодавства правила, за порушення яких адміністративну відповідальність передбачено статтями 152, 159 і 182 КУпАП. Проаналізувавши положення даної статті, побачимо, що законодавець сконцентрував у ній такі підходи: перший, що міститься в ч. 1 ст. 5 КУпАП, і який зазначає про те, що органи місцевого самоврядування безпосередньо у своїх рішеннях фіксують зобов' язуючі норми в частині, 
що стосується рішень із питань боротьби зі стихійним лихом й епідеміями, які передбачають за їх порушення адміністративну відповідальність, не вказуючи на норми, згідно з якими, власне, і настає адміністративна відповідальність. Тобто органи місцевого самоврядування у своїх рішеннях визначають перелік прав та обов'язків, котрими можуть користуватися суб'єкти правовідносин, і за невиконання яких наступає адміністративна відповідальність. Другий підхід полягає в тому, що органи місцевого самоврядування визначають перелік прав та обов' язків суб' єктів правовідносин, за недодержання котрих настає адміністративна відповідальність за вчинення конкретних (визначених) адміністративних правопорушень (це стосується рішень із питань боротьби з епізоотіями, за порушення яких відповідальність встановлено статтею 107 КУпАП, тобто конкретизується норма КУпАП, за котрою й настає адміністративна відповідальність. Фактично аналогічне положення міститься й у ч. 2 ст. 5 КУпАП). У такий спосіб делегування повноважень органам місцевого самоврядування надано повноваження встановлювати позитивні норми, порушення яких тягне за собою адміністративну відповідальність [17, с. 48-49]. Ведучи мову щодо визначення складу правопорушення в контексті ст. 5 КУпАП, слід зазначити, що норми вказаної статті непрямо наділяють органи місцевого самоврядування правом визначати діяння (об'єктивна сторона) та об'єкта, котрі безпосередньо в сукупності 3 іншими обов'язковими ознаками адміністративного правопорушення, а саме суб'єктом та суб'єктивною стороною й дають можливість про сприйняття конкретного діяння, як адміністративного правопорушення, адже в рішеннях органів місцевого самоврядування визначаються позитивні зобов' язання, що повинні вчинити учасники правовідносин, які заохочуються органами місцевого самоврядування й не сприймаються, як адміністративні правопорушення. Натомість адміністративна відповідальність настає за порушення цих правил, що безпосередньо відображається в нормах особливої частини КУпАП, якими й встановлюється адміністративна відповідальність за вчинення того чи іншого адміністративного правопорушення [17, с. 51]. Перш за все маємо звернути увагу на ту обставину, що Законом України «Про внесення змін до деяких законодавчих актів України, спрямованих на запобігання виникненню і поширенню коронавірусної хвороби (COVID-19)», не враховувалася необхідність підтримання системності адміністративно-деліктного законодавства, свідченням чого $є$ невнесення змін до ст. 5 КУпАП, а наслідком - неможливість застосування адміністративної відповідальності за ст. 443 КУпАП, за порушення обмежень, встановлених органами місцевого самоврядування, оскільки в нормі ч. 1 ст. 5 КУпАП імперативно визначено, що адміністративна відповідальність за такі обмеження може наставати виключно за ст. 107 КУпАП. Натомість норма ст. $44^{3}$ КУпАП містить вказівку на те, що вказані правила можуть встановлюватися органами місцевого самоврядування. Висновки дослідження правових підстав вставлення карантинних, санітарно-гігієнічних та санітарно-протиепідемічних норм і правил, дозволяють вмотивовано та обгрунтовано доводити законність підстав для встановлення вказаних обмежень та належним чином обгрунтувати учасникам відносин законність таких рішень і необхідність їх дотримання чи виконання. Водночас виникає конкуренщія норм Загальної та Особливої частин КУпАП. 
Детальніше дослідимо ухвалені Кабінетом Міністрів України відповідні карантинні, санітарно-гігієнічні та санітарно-протиепідемічні норми і правила, які були запроваджені під час карантину та зумовленого ним запровадження стану надзвичайної

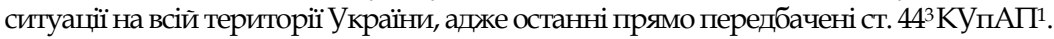

У тексті Постанови Кабінету Міністрів України від 11 березня 2020 р. № 211 «Про запобігання поширенню на території України гострої респіраторної хвороби COVID-19, спричиненої коронавірусом SARS-CoV-2», у редакції постанови Кабінету Міністрів України від 16 березня 2020 року № 215 [18] визначені заборони, яких слід дотримуватися громадянам у суспільних відносинах, а відповідно до змін, внесених постановою Кабінету Міністрів Украӥни від 2 квітня 2020 р. № 255, встановлено додаткові заборони, недотримання яких є підставою для притягнення до адміністративної відповідальності. указані підзаконні акти не формулюють складу правопорушення - вони визначають позитивні зобов' язання, яких слід дотримуватися громадянам, аби уникати адміністративної відповідальності. Важливим для об'єктивної сторони даного правопорушення є умови, за яких вони вчиняються, - громадські місця. Нагадаємо, що легальне визначення, яким на нашу думку, слід користуватися під час вирішення питання про застосування до особи заходів адміністративної відповідальності та відповідного державного примусу, визначено в нормі Закону Украӥни «Про заходи щодо попередження та зменшення вживання тютюнових виробів і їх шкідливого впливу на здоров'я населення» [19]. Громадське місце - частина (частини) будь-якої будівлі, споруди, яка доступна або відкрита для населення вільно чи за запрошенням, або за плату, постійно, періодично або час від часу, в тому числі під'їзди, а також підземні переходи, стадіони. Незважаючи на те, що вказаний термін пропонується вживати звиключно для цілей Закону України «Про заходи щодо попередження та зменшення вживання тютюнових виробів і їх шкідливого впливу на здоров'я населення», однак за відсутності іншого легального визначення цього поняття, переконані, слід використовувати саме таке поняття громадського місця.

Надалі Уряд України своєю постановою від 4 травня 2020 р. № 343 у постанові Кабінету Міністрів України від 11 березня 2020 р. № 211 ряд обмежень виклав у новій редакції [20], тим самим підкресливши, що позитивні зобов'язання, ухвалені органами виконавчої влади або місцевого самоврядування є динамічними, напряму залежними від епідемічного стану та поширення коронавірусної інфекції. Відтак під час встановлення складу адміністративного правопорушення слід ретельно вивчати останні зміни до законодавства, які можуть містити нові обмеження.

Підсумовуючи проведений аналіз, зазначимо, що об' єктивною стороною адміністративного правопорушення, передбаченого ст. $44^{3}$ КУпАП, залишається таке: 1) порушення правил щодо карантину людей, 2) порушення санітарно-гігієнічних правил і норм, 3) порушення санітарно-протиепідемічних правил і норм, що характеризуються відсильним характером їх викладу, вимагаючи вказувати ті запроваджені позитивні зобов'язання, які встановлені постановами Кабінету Міністрів України щодо заборон: 1) відвідування закладів освіти ііі здобувачами; 2) проведення

\footnotetext{
1 Нагадаємо, що адміністративна відповідальність поряд з іншим настає за порушення правил щодо карантину юдей, санітарно-гігієнічних, санітарно-протиепідемічних правил і норм, передбачених іншими актами законодавства, до яких належать постанови Кабінету Міністрів України.
} 
масових заходів; 3) роботи суб'єктів господарювання, пов'язаних із прийняттям відвідувачів ; 4) регулярних та нерегулярних перевезень пасажирів автомобільним транспортом у приміському, міжміському внутрішньообласному й міжобласному сполученні (крім перевезення легковими автомобілями); 5) перевезень пасажирів метрополітенами; 6) перевезень пасажирів залізничним транспортом; 7) перебування в громадських місцях без вдягнутих засобів індивідуального захисту, зокрема респіратора або захисної маски; 8) самовільного залишати місця обсервації (ізоляції); 9) перебування на вулицях без документів, що посвідчують особу, підтвердження громадянства чи ії спеціального статусу; 10) відвідування установ і закладів, що надають паліативну допомогу, соціального захисту; 11) відвідування пунктів тимчасового перебування іноземців та осіб без громадянства, які незаконно перебувають в Україні тощо. Перераховані діяння не є абсолютно визначеними, а можуть доповнюватися або скорочуватися, оскільки останні ухвалюються вищезазначеними суб'єктами органами державної влади та місцевого самоврядування.

Укотре наголосимо, що об'єктивна сторона полягає в порушенні правил щодо карантину людей, санітарно-гігієнічних, санітарно-протиепідемічних правил і норм, які можуть виявлятися у вчиненні або невчиненні перерахованих вище діянь. Водночас слід мати на увазі, що такі діяння можуть змінюватися і залежать від суб'єктів, які уповноважені встановлювати такі обмеження.

Нормою ст. 12 КУпАП визначено загального суб'єкта адміністративної відповідальності, а саме зазначається, що адміністративній відповідальності підлягають особи, які досягли на момент вчинення адміністративного правопорушення шістнадцятирічного віку. Одночасно в ст. 14 КУпАП міститься норма, якою визначається, що посадові особи підлягають адміністративній відповідальності за адміністративні правопорушення, пов'язані з недодержанням установлених правил у сфері охорони порядку управління, державного і громадського порядку, природи, здоров'я населення та інших правил, забезпечення виконання яких входить до їхніх службових обов'язків. За порушення санітарних норм на загальних підставах підлягають адміністративній відповідальності й військовослужбовці та інші особи, на яких поширюється дія дисциплінарних статутів, за вчинення адміністративних правопорушень (ст. 15 КУпАП).

Системно підходячи до аналізу змісту ст.ст. 12-16 КУпАП та ст. 443 КУпАП зауважимо, що суб'єктом адміністративної відповідальності за вчинення адміністративних правопорушень, відповідальність за які передбачена ст. 443 КУпАП, є: 1) загальний суб'єкт - особа, яка досягла на момент вчинення адміністративного правопорушення шістнадцятирічного віку; 2) спеціальний суб'єкт - суб'єкт господарювання; посадові особи, наділені відповідними організаційно-розпорядчими та управлінськими повноваженнями.

Четвертий елемент - суб' єктивна сторона адміністративного правопорушення вказує на психічний стан особи в момент здійснення нею адміністративного правопорушення. Зміст їі складає одна з форм вини (намір або необережність) суб'єкта протиправного діяння, що є обов'язковою умовою притягнення його до адміністративної відповідальності. Суб'єктивна сторона має декілька складових, до яких належать вина правопорушника, а також мета й мотив його діяльності. Визначальне місце при цьому займає вина як найважливіша суб'єктивна основа, без якої правова відповідальність не може мати місця [21, с. 26]. 
Вина - основна й обов'язкова ознака суб́'єктивноїсторони будь-якого адміністративного проступку. Це психічне ставлення особи до вчиненого нею суспільно шкілпивого діяння і його наслідків, яке виявляється у формі умислу або необережності [22, с. 20].

Відповідно до норм ст.ст. 10, 11 КУпАП, адміністративне правопорушення може бути вчиненим умисно, коли особа, яка його вчинила, усвідомлювала протиправний характер своєї дії чи бездіяльності, передбачала її шкідливі наслідки й бажала їх або свідомо допускала настання цих наслідків або з необережності, коли особа, яка його вчинила, передбачала можливість настання шкідливих наслідків свосї дії чи бездіяльності, але легковажно розраховувала на їх відвернення або не передбачала можливості настання таких наслідків, хоч повинна була й могла їх передбачити.

Таким чином, стверджуємо, що адміністративне правопорушення за ст. 443КпАП може бути вчинено як умисно, так і з необережності.

Висновки. Для дотримання фундаментальних принципів права і законодавства, таких як: дотримання прав і свобод людини та громадянина, верховенства права, законності у діяльності державних органів, органів місцевого самоврядування, їх посадових осіб, - важливим є розуміння змісту складу адміністративного правопорушення за ст. 443 КУпАП. Досягнути цього можливо, за умови, по-перше, уніфікації норм Загальної та Особливої частин КУпАП, зокрема внесення змін до ст. 5 КУпАП, а саме в ч. 1 ст. 5 КУпАП, викласти в наступній редакції: «Сільські, селищні, міські, обласні ради мають право приймати $B$ межах, що визначаються законами, рішення з питань боротьби зі стихійним лихом і епідеміями, які передбачають за їх порушення адміністративну відповідальність, а також рішення з питань боротьби з епідеміями, епізоотіями, за порушення яких відповідальність встановлено статтями 44" та 107 иъього Кодексу», а в ч. 2 ст. 5 КУпАП, після слова «статтями» доповнити «443», а далі за текстом.

Вважаємо, що зрозумілість норми, якою встановлено адміністративну відповідальність за ст. 44КУпАП, дотягнеться, коли розмежувати адміністративну відповідальність фізичних осіб та посадових осіб, юридичних осіб та фізичних осіб підпгриємщів. Переконані, що це можливо досягнути, коли в ст. 443 КУпАП сформувати дві частини: частина перша формулюватиме об'єктивну сторону, суб'єктом вчинення якої буде фізична особа, а частина друга - суб'єктом вчинення визначатиме юридичну особу або фізичну особу - підприємця, що дозволить диференційовано підійти й до встановлення санкцій.

Думається, що ухвалення вказаних змін слугуватиме доступності, прозорості та зрозумілості адміністративно-деліктного законодавства, норми якого ефективно слугуватимуть цілям запровадження адміністративної відповідальності, спрямованих на якісне врегулювання суспільних відносин із дотримання карантинних обмежень, спрямованих на стримання поширенню коронавірусної інфекції.

\section{Використані джерела:}

1. Самбор М. Ефективність адміністративно-деліктного права України. Вісник Київського національного університету імені Тараса Шевченка. Юридичні науки. 2016. № 2 (103). С. 45-48.

2. Мазуренко В. І. Самбор М. А., Гудович О. Д. Правові основи тактики дій поліцейських в умовах надзвичайних ситуацій. Науковий Збірник ІДУЦЗ. 2018 №6. С. 122-140

3. Сергеєв А. В. Правові основи діяльності органів внутрішніх справ в умовах надзвичайних ситуащій техногенного та природного характеру. Право і безпека. 2002. № 2. С. 118-120. 
4. Кодекс України про адміністративні правопорушення від 7 грудня 1984 року. URL: https:/ zakon.rada.gov.ua/laws/show/80731-10\#Text (статті 1 - 212-20) та https:/ / zakon. rada.gov. ua/laws/show/80732-10\#top (статті 213 - 330). (дата звернення: 17.06.2020).

5. Про внесення зміндо деяких законодавчих актів України, спрямованих на запобігання виникненню і поширенню коронавірусної хвороби (COVID-19): закон Украӥни від 17 березня 2020 року. URL: https:/ / zakon.rada.gov.ua/laws/show/530-20\#Text. (дата звернення: 17.06.2020).

6. Пояснювальна записка 16.03.2020 до проекту закону України про внесення змін до деяких законодавчих актів України, спрямованих на запобігання виникнення і поширення коронавірусної хвороби (COVID-19) URL: https://w1.c1.rada.gov.ua/pls/zweb2/webproc4_1?pf3511 =68397. (дата звернення: 17.06.2020).

7. Висновок Головного науково-експертного управління на проект Закону Украӥни «Про внесення змін до деяких законодавчих актів України, спрямованих на запобігання виникнення і поширення коронавірусної хвороби (COVID-19)», реєстраційний номер № 3219 від 16.03.2020. URL: https://w1.c1.rada.gov.ua/pls/zweb2/webproc4_1?pf3511=68397. (дата звернення: 17.06.2020).

8. Колпаков В. К. Адміністративна відповідальність (адміністративно-деліктне право): навч. посіб. К.: Юрінком Інтер, 2008. 256 с.

9. Административная ответственность: учеб. пособие для студентов вузов, обучающихся по специальности «Юриспруденция» / [А. И. Стахов, Н. В. Румянщев, С. Н. Бочаров идр.]; под ред. А. И. Стахова, Н. В. Румянщева. [7-е изд., перераб. и доп.]. М.: ЮНИТИ-ДИАНА: Закон и право, 2012.231 c.

10. Чишко К.О. Класифікація об'єктів адміністративних правопорушень у сфері забезпечення громадського порядку та громадської безпеки. Право і суспільство. 2016. № 2. Частина 3. С. 135-142.

11. Гуржій А. В., Мельник Ю. О. Об'єкт правопорушення як критерій структуризації адміністративно-деліктного законодавства. Юридична наук. 2015. № 4. С. 14-19.

12. Основи законодавства України про охорону здоров'я: закон України від 19 листопада 1992 року. URL: https:/ / zakon.rada.gov.ua/laws/show/2801-12\#Tеxt (дата звернення: 22.06.2020).

13. Окерешко М. В.Поняття ісклад адміністративного правопорушення, вчиненого лікарем у сфері охорони здоров'я населення. Молодий виений. травень 2017. № 5.1 (45.1). С. 80-84. URL: http:/ / molodyvcheny.in.ua/files/journal/2017/5.1/21.pdf. (дата звернення: 18.06.2020).

14. Об'єктивна сторона адміністративного правопорушення. URL: https:/ / jurisprudence. club/administrativnoe-uchebnik/obektivna-storona-administrativnogo.html. (дата звернення: 17.06.2020).

15. Рішення Конституційного Суду Украӥни від 9 липня 1998 року № 12-рп/98 у справі № 17/81-97, 1-1/98 за конституційним зверненням Київської міської ради професійних спілок щодо офіційного тлумачення частини третьої статті 21 Кодексу законів про працю України (справа про тлумачення терміну «законодавство»). URL: https://zakon. rada.gov.ua/ laws/show/v012p710-98. (дата звернення: 10.06.2020).

16. Про місцеве самоврядування в Україні: закон України від 21 травня 1997 року. URL: https:/ / zakon.rada.gov.ua/laws/show/280/97-\%D0\%B2\%D1\%80\#Tеxt. (дата звернення : 11.06.2020).

17. Самбор М. А., Самбор А. М. Повноваження органів місцевого самоврядування щодо прийняття рішень, якими визначаються склади адміністративних правопорушень. Наукові записки Інституту законодавства Верховної ради Украӥни. 2014. № 3. С. 47-53.

18. Про запобігання поширенню на території України гострої респіраторної хвороби COVID-19, спричиненої коронавірусом SARS-CoV-2: постанова Кабінету Міністрів України від 11 березня 2020 р. № 211. URL: http://search.ligazakon.ua/__doc2.nsf/link1/KP200211.html (дата звернення: 19.03.2020). 
19. Про заходи щодо попередження та зменшення вживання тютюнових виробів і їх шкідливого впливу на здоров'я населення: закон України від 22 вересня 2005 року. URL: https://zakon.rada.gov.ua/laws/show/2899-15\#Text (дата звернення: 22.06.2020).

20. Про внесення змін до деяких актів Кабінету Міністрів України: постанова Кабінету Міністрів України від 4 травня 2020 р. № 343. URL: https:/ /zakon.rada.gov.ua/laws/show/3432020-\%D0\%BF\#n11. (дата звернення: 19.06.2020).

21. Бєлікова О. В. Юридичний склад адміністративного правопорушення. Держава та регіони. Серія: право, 2013 р. № 3 (41). С. $22-28$.

22. Кодекс України про адміністративні правопорушення: науково-практичний коментар / [Р. А. Калюжний, А. Т. Комзюк, О. О. Погрібний та ін.]. [2-ге вид.]. К.: Всеукраӥнська асоціащія видавців «Правова єдність», 2008. 655 с.

\section{References:}

1.Sambor, M. (2016) Efektyvnistadministratyvno-deliktnoho prava Ukrainy. Visnyk Kyivskoho natsionalnoho universytetu imeni Tarasa Shevchenka. Yurydychni nauky. -Bulletin of Taras Shevchenko National University of Kyiv. Legal sciences, 2 (103), 45-48. [in Ukrainian].

2. Mazurenko, V. I., Sambor, M. A., Gudovich, O. D. (2018) Pravovi osnovy taktyky dii politseiskykh v umovakh nadzvychainykh sytuatsii. Naukooyi Zbirnyk IDUTSZ - Scientific Collection of IDUCZ, 6, 122-140. [in Ukrainian].

3. Sergeev, A. V. (2002) Pravovi osnovy diyalnosti orhaniv vnutrishnikh sprav v umovakh nadzvychaynykh sytuatsii tekhnohennoho ta pryrodnoho kharakteru. Pravoi bezpeka-Law and security, 2, 118-120. [in Ukrainian].

4. Kodeks Ukrainy pro administratyvni pravoporushennia vid 7 hrudnia 1984 roku. (1984) N.p. URL: https://zakon.rada.gov.ua/laws/show/80731-10\#Text(Art.1-212-20) та https:// zakon. rada.gov.ua/laws/show/80732-10\#top (Art. 213 -330). [in Ukrainian].

5. Pro vnesennia zmin do deiakykh zakonodavchykh aktiv Ukrainy, spriamovanykh na zapobihannia vynyknenniu i poshyrenniu koronavirusnoi khvoroby (COVID-19): zakon Ukrainy vid 17 bereznia 2020 roku. (2020) N. p. URL: https://zakon.rada.gov.ua/laws/show/530-20\# Text. [in Ukrainian].

6. Poyasniuvalna zapyska 16.03 .2020 do proektu zakonu Ukrainy pro vnesennia zmin do deiakykh zakonodavchykh aktiv Ukrainy, spriamovanykh na zapobihannia vynyknennia i poshyrennia koronavirusnoi khvoroby (COVID-19). (2020) N. p. URL: https://w1.c1. rada.gov. ua/ pls/zweb2/webproc4_1?pf3511=68397. [in Ukrainian].

7. Vysnovok Holovnoho naukovo-ekspertnoho upravlinnia na proekt Zakonu Ukrainy «Pro vnesennia zmin do deiakykh zakonodavchykh aktiv Ukrainy, spriamovanykh na zapobihannia vynyknennia i poshyrennia koronavirusnoi khvoroby (COVID-19)», reestratsiinyi nomer № 3219 vid 16.03.2020. (2020) N. p. URL: https://w1.c1.rada.gov. ua/pls/zweb2/ webproc4_1?pf3511=68397. [in Ukrainian].

8. Kolpakov, V. K. (2008) Administratyvna vidpovidalnist (administratyvno-deliktne pravo. Kyiv, Yurinkom Inter. [in Ukrainian].

9.Stakhov, A. I., Rumyantsev, N. V., Bocharov, S. N. etal. (2012).Administrativnaia otvetstvennost: ucheb. posobie dlya studentov vuzov, obuchayushchikhsya po spetsialnosti «Yurisprudentsiya» $\mathrm{M}$. YUNITI-DIANA: Zakon i pravo. [in Russian].

10. Chyshko, K. O. (2016) Klasyfikatsiia obektiv administratyvnykh pravoporushen u sferi zabezpechennia hromadskoho poriadku ta hromadskoi bezpeky. Pravo i suspilstvo - Law and society, 2, part 3, 135-142. [in Ukrainian].

11. Hurzhii, A. V., Melnyk, Yu. O. (2015) Obiekt pravoporushennia yak kryterii strukturyzatsii administratyvno-deliktnoho zakonodavstva. Yurydychna nauka - Legal Science, 4, 14-19. [in Ukrainian]. 
12. Osnovy zakonodavstva Ukrainy pro okhoronu zdorovia: zakon Ukrainy vid 19 lystopada 1992 roku. (1992) N. p. URL: https:/ / zakon.rada.gov.ua/laws/show/2801-12\#Text. [in Ukrainian].

13. Okereshko, M. V. (2017) Poniattiai sklad administratyvnoho pravoporushennia, vchynenoho likarem u sferi okhorony zdorovia naselennia. Molodyi vchenyy - Young scientist, Traven, 5.1 (45.1), 80-84. URL: http://molodyvcheny.in.ua/files/journal/2017/5.1/21.pdf. [in Ukrainian].

14. Obiektyvna storona administratyvnoho pravoporushennia. N. d. N. p. URL: https:// jurisprudence.club/administrativnoe-uchebnik/obektivna-storona-administrativnogo.html. [in Ukrainian].

15. Rishennia Konstytutsiinoho Sudu Ukrainy vid 9 lypnia 1998 roku № 12-rp/98 u spravi № 17/81-97, 1-1/98 za konstytutsiinym zvernenniam Kyivskoi miskoi rady profesiinykh spilok shchodo ofitsiinoho tlumachennia chastyny tretoyi statti 21 Kodeksu zakoniv pro pratsiu Ukrainy (sprava pro tlumachennia terminu «zakonodavstvo»). (1998) URL: https:// zakon.rada.gov. ua/ laws/ show/ v012p710-98. [in Ukrainian].

16. Pro mistseve samovriaduvannia v Ukraini: zakon Ukrainy vid 21 travnia 1997 roku. (1997) URL: https://zakon.rada.gov.ua/laws/show/280/97-\%D0\%B2\%D1\%80\#Text. [in Ukrainian].

17. Sambor, M. A., Sambor, A. M. (2014) Povnovazhennia orhaniv mistsevoho samovriaduvannia shchodo pryiniattia rishen, yakymy vyznachaiutsia sklady administratyvnykh pravoporushen. Naukovi zapysky Instytutu zakonodavstva Verkhoonoi rady Ukrainy - Scientific Papers of the Legislation Institute of the Verkhorna Rada of Ukraine, 3, 47-53. [in Ukrainian].

18. Pro zapobihannia poshyrenniu na terytorii Ukrainy hostroi respiratornoi khvoroby COVID19, sprychynenoi koronavirusom SARS-CoV-2: postanova Kabinetu Ministriv Ukrainy vid 11 bereznya 2020 r. № 211. (2020) URL: http://search. ligazakon.ua/ 1_doc2.nsf/link1/ KP200211. html. [in Ukrainian].

19. Pro zakhody shchodo poperedzhennia ta zmenshennia vzhyvannia tiutiunovykh vyrobiv i yikh shkidlyvoho vplyvu na zdorovia naselennia: zakon Ukrainy vid 22 veresnia 2005 roku. (2005) N. p. URL: https:// zakon.rada.gov.ua/laws/show/2899-15\#Text. [in Ukrainian].

20. Pro vnesennia zmin do deiakykh aktiv Kabinetu Ministriv Ukrainy: postanova Kabinetu Ministriv Ukrainy vid 4 travnia 2020 r. № 343. (2020) N. p. URL: https:/ / zakon. rada. gov.ua/ laws show/343-2020-\%D0\%BF\#n11. [in Ukrainian].

21. Belikova, O. V. (2013) Yurydychnyi sklad administratyvnoho pravoporushennia. Derzhava ta rehiony. Seriya: prawo - State and regions. Series: Law, 3 (41), 22-28 [in Ukrainian].

22. Kalyuzhnyi, R. A., Komziuk, A. T., Pohribnyi, O. O. et al. (2008) Kodeks Ukrainy pro administratyvni pravoporushennia: naukovo-praktychnyi komentar Kyiv, Vseukrainska asotsiatsiia vydavtsiv «Pravova yednist». [in Ukrainian].

Стаття надіӥила до редколегії 23.06.2020

Самбор Н. А., кандидат юридических наук, начальник сектора мониторинга Прилуцкого отдела полищии Главного управления Национальной полиции в Черниговской области (г. Чернигов - г. Прилуки, Украина)

\section{СОСТАВ АДМИНИСТРАТИВНОГО ПРАВОНАРУШЕНИЯ ЗА НАРУШЕНИЕ ПРАВИЛ КАРАНТИНА ЛЮДЕЙ}

В статье исследуется состав административного правонарушения по ст. $44^{3}$ Кодекса Украины об административных правонарушениях, которой дополнен Кодекс законом 
Украины от 17 марта 2020 года. В условиях мирового и всеукраинской социальных кризисов, обусловленных распространением коронавирусной инфекции, угрожающей жизни и здоровью людей, Верховной Радой Украины введена административная ответственность за нарушение правил карантина людей. Норме ст. $44^{3}$ КУоАП со времени разработки законопроекта не присущи правовая определенность, ясность. Анализ этого административного правонарушения позволил сделать вывод о неоднозначности восприятия законности принятия органами местного самоуправления соответствующих ограничений, несоблюдение которых влечет административную ответственность по указанной статъе. Кроме того, установлено, что введенные изменения в КУоАП создали конкуренцию норм Общей и Особенной частей КУоАП. Неудачно изложена норма создает недоразумения и в выяснении субъекта правонарушения. Целесообразно было бы разграничить административную ответственность физических лищ и должностных лищ субъектов хозяйствования.

Ключевые слова: административноеправонарушение, юридический состав, правила карантина людей.

Sambor M.,

Ph. D. in Law, Head of the monitoring Department of the Pryluky Police Department the Main Directorate of the National Police in Chernihiv Region (Chernihiv - Pryluky, Ukraine)

\section{COMPOSITION OF ADMINISTRATIVE OFFENSES FOR VIOLATION OF THE HUMAN QUARANTINE RULES}

The article examines the composition of an administrative offense under Art. $44^{3}$ of the Code of Ukraine on Administrative Offenses, which supplemented the Code by the Law of Ukraine of March 17, 2020. In the context of global and national social crises caused by the spread of coronavirus infection, which threatens human life and health, the Verkhovna Rada of Ukraine introduced administrative liability for violating the rules on human quarantine. Norms of Art. $44^{3}$ CUAO since development of the bill legal certainty, clarity are not inherent. The analysis of the composition of this administrative offense allowed us to conclude that the perception of the legality of the adoption by local governments of the relevant restrictions, non-compliance with which entails administrative liability under this article.

The objective side of this offense is 1) violation of the rules for quarantine of people, 2) violation of sanitary and hygienic rules and regulations, 3) violation of sanitary and anti-epidemic rules and regulations. These acts can be committed in the form of action - active behavior, when the subject commits acts expressly prohibited by law, and inaction of the subject - passive behavior due to failure of the subject, established by law and defined in the decisions of local authorities municipality. The obligatory element of the objective side is the reference to the fact that the specified norms and rules should be contained in norms: 1) the Law of Ukraine «About protection of the population against infectious diseases», 2) other acts of the legislation, 3) decisions of local governments on questions control of infectious diseases.

In addition, it was found that the amendments to the Code of AdministrativeOffenses created competition between the norms of the General and Special Parts of the Code of Administrative Offenses. To comply with the fundamental principles of law and legislation, such as: observance of human and civil rights and freedoms, the rule of law, legality in the activities of state bodies, local governments, their officials - it is important to understand the content of administrative offenses under Art. $44^{3} \mathrm{CUAO}$. It is possible to achieve this, provided, first, the unification of the norms of the 
General and Special Parts of the Code of Administrative Offenses, in particular, amendments to Art. 5 CUAO.

Unsuccessfully stated norm creates misunderstandings in clarifying the subject of the offense. It would be advisable to distinguish between administrative liability of individuals and officials of economic entities.

We believe that the adoption of these changes will serve the accessibility, transparency and clarity of administrative tort law, the rules of which will effectively serve the purposes of administrative liability, aimed at quality regulation of public relations to comply with quarantine restrictions aimed at curbing the spread of coronavirus infection.

Keywords: administrative offense, legal structure, rules of quarantine of people.

DOI: $10.33766 / 2524-0323.90 .170-181$

УДК 342.951[342.7:614.253.8]

В. I. Теремецький, доктор юридичних наук, доцент, професор кафедри цивільного права і процесу

Тернопільського національного економічного університету

(м. Тернопіль, Україна) e-mail: vladvokat333@ukr.net iDhttps:/ /orcid.org/0000-0002-2667-5167 Г. В. Муляр, кандидат історичних наук, доцент, доцент кафедри кримінального права, процесу та криміналістики Академії праці, соціальних відносин і туризму (м. Київ, Україна) e-mail: box0007@meta.ua iDhttps://orcid.org/0000-0003-2636-0509

\section{АДМІНІСТРАТИВНО-ПРАВОВЕ ЗАБЕЗПЕЧЕННЯ ПРАВ ПАЛІАТИВНИХ ПАЩСНТІВ: УКРАЇНСЬКИЙ ТА МГЖНАРОДНИЙ ДОСВІД}

У статті проаналізовано стан нормативно-правового забезпечення паліативноїдопомоги у с віті та в Україні. Виділено структурні елементи механізму адміністративно-правового забезпечення прав паліативних пацієнтів. Підтримано пропозиції вчених щодо доцільності розробки й затвердження Державної програми розвитку паліативної та хоспісної допомоги, а також створення Національної Координаційної Ради з питань паліативної та хоспісної допомоги. Запропоновано привести у відповідність до міжнародних стандартів методичну базу та медичні протоколи лікування паліативних хворих; передбачити можливість отримання бюджетних коштів недержавними суб'єктами; сформувати ефективну систему підготовки та підвищення кваліфікації медичних та соціальних працівників, які надають паліативну допомогу; посилити санкції за порушення законодавства про захист персональних даних.

Ключові слова: пацієнт, паліативна допомога, права паліативних пацієнтів, медична допомога, хоспіс.

(C) Теремецький B. I., Муляр Г. В., 2020 